\title{
Reliability of Palaeomagnetism for Research in Palaeogeography
}

\author{
By Ting-Ying $\mathrm{H}$. Ma \\ National Taiwan University, Taipei, Taiwan, China
}

\section{Introduction}

After discovering seasonal change of growth in the skeletal tissue of reef corals in 1933 (Ma, 1933), I found in further research that the annual growth value of reef corals is closely related to the temperature of surface sea water ( $\mathrm{Ma}, 1937 \mathrm{c}$ ) and used the annual growth values of fossil reef corals to prove that the Palaeozoic positions of the poles and configuration of the continents were all different from at present (Ma, 1937a, 1937b). In the continued researches I understood that such ${ }^{-1}$ ifferences in latitude lie in the sudden total displacement of the solid earth shell and the individual drift of continents (Ma, 1943, 1943a, 1943b, 1952, 1953, 1955a, 1955c, 1957, 1960). Thus the fossil coralline seas shifted away from the tropics and subtropics and broken into segments not on a great circle proved polar wandering and drift of continents, and the next step was to follow out the consecutive displacements of the solid earth shell and the course of shifting of crustal masses (Ma, 1952, 1957) to understand their mode and their effects on geography, geology, oceanography and geophysics (Ma, 1955a, 1955b, 1957, 1960, 1961a). In all these years, except for determining clearly the latitudinal positions of various continents from the Ordovician to the Permian in the Palaeozoic (Ma, 1955, 1956, 1956a, 1956b, 1960, 1961) and for the Upper Cretaceous in the Mesozoic (Ma, 1957a), I have used two great strides made in geophysics to help clarify the mode of such catastrophic events in the history of the earth to explain geological features and structures as their effects (Ma, 1955a, 1955b, 1957, 1960, 1961a). The shear plane represented by earthquake foci is interpreted as from overthrust of one crustal mass over another, and the zone of deficient gravity is interpreted as due to multi-folding of the sial layer by the overthrust (Ma, 1957; Ma \& Pan, 1955). Such interpretations make them key functions for explaining the complicated tectonic patterns and geomorphological features especially around the Pacific (Ma, 1957b, 1960c). The recent proving by geomagnetism of changes of latitude that are not coordinated on different continents is an independent proof of polar wandering and continental drift which I am very glad to hear of, for it has not only cleared off the adverse opinions but also aroused wide discussion in this direction so that symposia were held on polar wandering and continental drift during the past few years. However, I have gone into the effects of the sudden change of pole positions and continental drift from high mountain glaciers (Ma, 1961a) down to submarine geology ( $\mathrm{Ma}, 1960 \mathrm{c}$ ) and my determination of latitudes independent of magnetism is here used to judge magnetic results according to my logic 
for all to consider.

As an onlooker to palaeomagetic research, it seems to me that there are three puzzling problems which can be resolved with palaeogeographic latitudes determined from biological data. These are: (1) palaeomagnetism itself cannot determine exactly how much of the difference of a palaeomagnetic latitude from the present geographical latitude is due to change of pole positions and how much due to continental drift; (2) when magnetic pole positions determined from different positions on the same continent, such as Eastern Asia and Western Europe on Eurasia, are far apart, there is no way to judge how each is right or wrong to what degree; and (3) when the palaeomagnetic inclination determined at one place is different for different specimens of magnetized rocks, it is hard to choose between them. My last paper on palaeomagnetism (Ma, 1960b), based on very little data, was insufficient to do more than try my way of solving these problems. In this paper, I have mainly used the data collected in a paper by Cox and Doell (1960) to make a comparison for six periods of the Palaeozoic and one in the Mesozoic to discuss how to judge the reliability of palaeomagnetism for research in palaeogeography.

\section{Comparison}

As mentioned in my previous paper ( $\mathrm{Ma}, 1960 \mathrm{~b}$ ), in making comparison we must first remember that the present magnetic poles are not coincident with the geographical poles and therefore a difference of less than 22 degrees can be interpreted as agreement. The pole position determined by palaeomagnetism, however, is liable to error due to the rotation of minor blocks in situ and major change of intra- and inter-continental oositions among crustal masses (Ma, 1960). Therefore the magnetized rock is in seneral of little use for determining pole position especially of Palaeozoic and Mesozoic jeriods.

The magnetic inclinations in Eurasia, Africa, North America and Australia and the magnetic poles given for the seven periods in Table I-Palaeomagnetic Data from the paper Review of Paleomagnetism by Cox and Doell (1960) are tabulated against the latitudinal positions determined from the fossil coralline seas and the geographical pole positions determined separately with respect to the fossil coralline seas on Eurasia and on North America for comparison as on the next page:

\section{Interpretation and Conclusion}

(I) Reliability of Palaeomagnetic Latitudes: From the table given on the next page it is clear that:

(1) Of the magnetic measurements of Ordovician rocks at the two locations in Eurasia the inclination at Leningrad is quite in agreement with the corresponding geographical latitude and that in Ukraine a little greater to coordinate with the latitude, explainable as due to the change of intra-continental position of the crustal mass; and at the three locations in North America only the inclination of the late Ordovician sediments from the Juniata Formation in Pennsylvania is in agreement with the geo- 


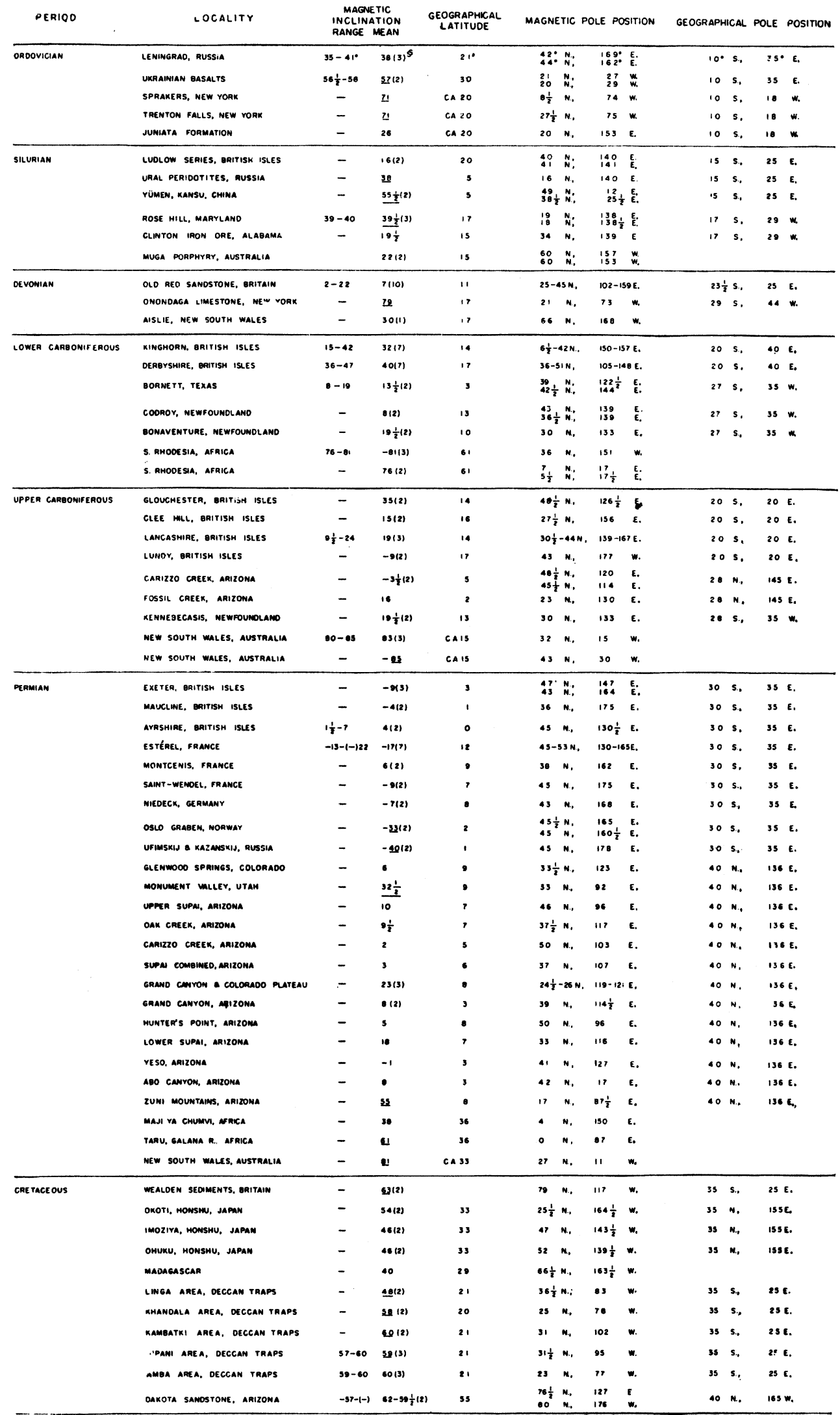


graphical latitude and those at Sprakers in New York and Trenton Falls are both too great for coordinating with the low latitudes of the fossil coralline sea in which the locations fall.

(2) At the seven locations of the magnetic measurements of Silurian rocks, only the inclination in Yumen, Kansu, China and the Urals in Russia are too great to coordinate with the corresponding latitudes, and from the fact that both these two locations are surrounded by regions of fossil reef corals with large annual growth values or without seasonal change in growth (Ma, 1943a, 1956a), the contradiction can not be explained by major change of intra-continental positions.

(3) At the three locations of magnetic surveys of Devonian rocks, the inclination at only a single location in North America is too great for coordinating with the corresponding latitude low in the coralline sea (Ma, 1943b, 1956) so that the wrong inclination there is unpermissible, while the other two inclinations in the British Isles and Australia are respectively very well in agreement with the corresponding latitudes.

(4) The magnetic inclinations of the Lower Carboniferous rocks from locations both in Eurasia and North America are all in agreement with the corresponding latitudes; and in Africa, the magnetic inclinations measured on samples of the Dwyka Varved Clay from Subungwe, South Rhodesia, ranges from $76^{\circ}$ to $81^{\circ}$, while the position of this place during the Lower Carboniferous was at present $8^{\circ} \mathrm{N}$., $45^{\circ} \mathrm{E}$. as shown in Figure 4b ( $\mathrm{Ma}, 1955)$, so that the palaeogeographical latitude determined from the central line of the fossil coralline sea on Eurasia should be 61 degrees. This is quite good agreement. Thus the magnetic inclination supports the rotation of Africa from the west coast of India (Ma, 1951, 1952).

(5) Measurements of magnetic inclinations of the Upper Carboniferous rocks at the locations in both Eurasia and North America are all in agreement with the corresponding latitudes, but those in New South Wales in the southeastern corner of Australia are too great to correspond to the low latitudes of the coralline sea on that continent (Ma, 1961a).

(6) Among the measurements at the nine locations of Permian rocks in Europe the magnetic inclinations are too great to coordinate with the corresponding latitudes in only two regions, Oslo in Norway and Ufimakij and Kazanskij in Russia, both situated in the Permian coralline sea on Eurasia (Ma, 1961); in Africa the magnetic inclinations of the Upper and Lower Permian rocks in the single locality have been measured and the former is very well in agreement with the corresponding latitude while the latter is too great; among the nine locations in North America in only one location is the magnetic inclination of the Permian rocks too great to coordinate with corresponding latitude; and in Australia one group of the Permian rocks measured in New South Wales which was situated then in the coralline sea (David, 1950; Ma, 1961a,), shows too great magnetic inclination to coordinate with the corresponding latitude.

(7) The inclinations of Cretaceous rocks in Japan and Madagascar are both in 
coordination with the corresponding latitudes, while in both the British Isles and India, the magnetic inclinations are too great to coordinate with the low latitudes in the fossil coralline sea (Duncan, 1861, 1869-70, 1880, Ma, 1951, 1957a). Even when magnetization of the rocks in the Deccan Traps is looked upon as belonging in the Eocene, the locations in India still fall in the Eocene coralline sea on Eurasia since surrounded by scattered localities of Eocene reef corals (Gregory, 1930; Stoliczka, 1873), so that the Cretaceous inclination of the magnetized rocks in India must be jndged as unsuitable for interpreting polar wandering and continental drift.

As summed up above, the reliability is as a whole very great when latitudes are determined from palaeomagnetic inclinations measured in situ over all the world, but there are liable to be a small minority of the magnetic measurements contradictory to the geographical latitudes, as the two out of three locations of Ordovician measurements in North America, the single location of Silurian measurements in Kansu, China and that in the Urals, Russia, the single location for both the Upper Carboniferous and Permian measurements in Australia, the single location of Cretaceous measurements in the British Isles, and all six of the Cretaceous measurements of locations in India, which would lead into serious error when used for following out polar wandering and continental drift. Therefore the magnetic data must be checked with reliable biological research as I have done with corals in order to eliminate the unexpected contradictions of indeterminate origin.

(II) Reliability of the Palaeomagnetic Poles Deduced from the Declination of Remanent Magnetism: When we know that a great majority of the palaeomagnetic inclinations coordinate in situ with the geographical latitudes, we naturally expect that the palaeomagnetic poles determined with both the inclination and declination of remanent magnetism in rocks should be correct. Actually, aside from the disagreement of palaeomagnetic poles from different continents, the palaeomagnetic poles determined even from the same continent fall in different positions, and even in the geographical tropics and subtropics. As shown in Figures $4 \mathrm{a}$ and $4 \mathrm{~b}$, the magnetic poles of the Lower Carboniferous from Europe fall far away from the geographical pole positions, mostly in low latitudes of the inner belt of the Lower Carboniferous coralline sea in Asia and the rest in the outer belt. For the other five periods of the Palaeozoic, the magnetic poles also partly or mostly fall in the corresponding coralline seas. This shows that the relative drift of continents and the rotation of individual crustal masses as well as changes in intra-continental positions must be considered besides the folding and tilting of strata already considered in magnetic measurements.

Even in quiet geological times as at present, in earthquake belts as in the Japanese Islands, it is possible to recognize that crustal blocks have suffered translation and rotation. As I have repeatedly pointed out (Ma, 1957, 1960), the sudden total displacement of the solid earth shell results in shaking up of crustal masses for rotation of individual crustal masses and blocks and major changes of intra-continental positions. The eastern edge of Asia has shifted over 1,000 km. into the Pacific since the end of the Palaeozoic and Africa has rotated away from the west coast of India since the 
Early or Middle Tertiary (Ma, 1951). Considering such major shifts, the Palaeozoic and Mesozoic magnetic declinations have suffered changes and must be corrected before they can point to a position of the magnetic pole at a distance determined from the inclination, and even when so corrected other crustal masses than originally there might have shifted in to confuse the geographical position of magnetic pole. However, I do not point to this weakness of magnetic data to discredit them and I must say that they are still useful after the geographical latitudes are determined with respect to biological data, for they can be very useful in determining the translation of the crustal mass on which inclination and declination are measured so that they would be very important for studying crustal movements.

It is quite wonderful that the palaeomagnetic pole positions determined from North America for the six Palaeozoic periods and the Cretaceous mostly agree with the corresponding geographical positions, although falling in the fossil coralline seas of the respective periods in Eastern Asia due to subsequent drift of North America. The geographical pole positions in the present Northern Hemisphere determined separately from the central line of the fossil coralline seas on Eurasia and on North America are tabulated as follows:

\begin{tabular}{|c|c|c|c|c|}
\hline \multirow[t]{2}{*}{ Period } & \multicolumn{2}{|c|}{$\begin{array}{l}\text { Pole-position from the } \\
\text { central line of fossil } \\
\text { coralline sea on Eurasia }\end{array}$} & \multicolumn{2}{|c|}{$\begin{array}{l}\text { Pole-position from the central } \\
\text { line of fossil coralline sea } \\
\text { on North America }\end{array}$} \\
\hline & Latitude & Longitude & Latitude & Longitude \\
\hline Ordovician $\ldots \ldots \ldots \ldots$ & $10^{\circ} \mathrm{N}$ & $145^{\circ} \mathrm{W}$ & $10^{\circ} \mathrm{N}$ & $162^{\circ} \mathrm{E}$ \\
\hline Silurian $\ldots \ldots \ldots \ldots \ldots$ & $15^{\circ} \mathrm{N}$ & $165^{\circ} \mathrm{W}$ & $17^{\circ} \mathrm{N}$ & $151^{\circ} \mathrm{E}$ \\
\hline Devonian $\ldots \ldots \ldots \ldots \ldots$ & $23 \frac{1}{2}^{\circ} \mathrm{N}$ & $155^{\circ} \mathrm{W}$ & $29^{\circ} \mathrm{N}$ & $136^{\circ} \mathrm{E}$ \\
\hline Lower Carboniferous...... & $20^{\circ} \mathrm{N}$ & $140^{\circ} \mathrm{W}$ & $27^{\circ} \mathrm{N}$ & $155^{\circ} \mathrm{E}$ \\
\hline Upper Carboniferous...... & $20^{\circ} \mathrm{N}$. & $160^{\circ} \mathrm{W}$ & $28^{\circ} \mathrm{N}$ & $145^{\circ} \mathrm{E}$ \\
\hline Permian............... & $30^{\circ} \mathrm{N}$. & $145^{\circ} \mathrm{W}$ & $40^{\circ} \mathrm{N}$ & $136^{\circ} \mathrm{E}$ \\
\hline Upper Cretaceous ....... & $35^{\circ} \mathrm{N}$ & $155^{\circ} \mathrm{W}$ & $40^{\circ} \mathrm{N}$ & $165^{\circ} \mathrm{E}$. \\
\hline
\end{tabular}

For easier comparison, palaeomagnetic poles determined from Eurasia and North America are inserted in Figures 1a-7a and palaeomagnetic poles determined from Europe and Cretaceous magnetic poles determined from Japan inserted in Figures $1 \mathrm{~b}-7 \mathrm{~b}$. It is not hard to see that the magnetic poles determined from North America almost all correspond with the geographical pole positions determined from the North American fossil coralline seas. This is a sharp contrast with the disagreement of the magnetic poles determined from Europe and the geographical pole positions determined from the fossil coralline seas on Eurasia which has suffered changes in intra-continental positions, as can be seen in Figures $1 b-7 b$.

The respective pairs of geographical pole positions determined relative to the present mesh of latitudes and longitudes on Eurasia after first adjusting the coralline seas in North America and Eurasia into a great circle all fall in south of the equator in present Africa and diametically in the North Pacific. The Palaeozoic magnetic poles determined from these respective geographical pole positions and fall mostly in 


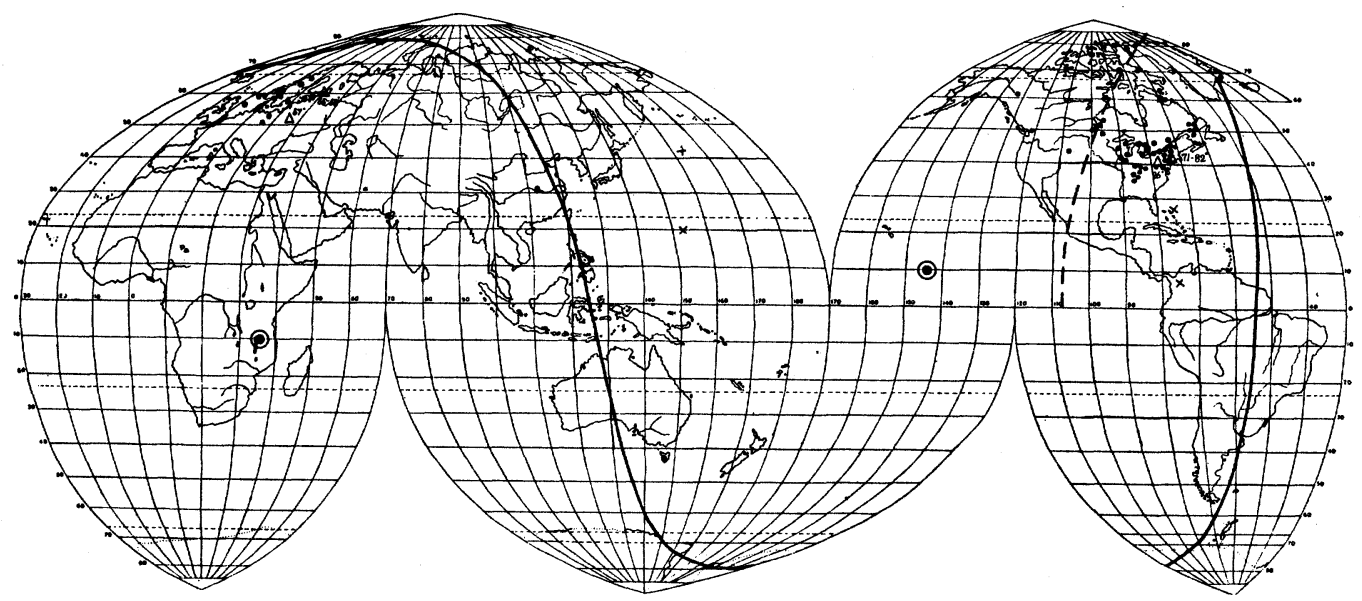

The Ordovician equator with respect to the present mesh of latitudes and longitudes on Eurasia and the corresponding poles.

The Ordovician equator with respect to the present mesh of latitudes and longitudes on North America.

- Localities of fossil corals.

$\triangle$ Magnetic latitudes.

+ Magnetic poles from Europe $\times$ Magnetic poles from North America.

Fig. 1a The alignment of segments of the Ordovician coralline sea on the present continents.

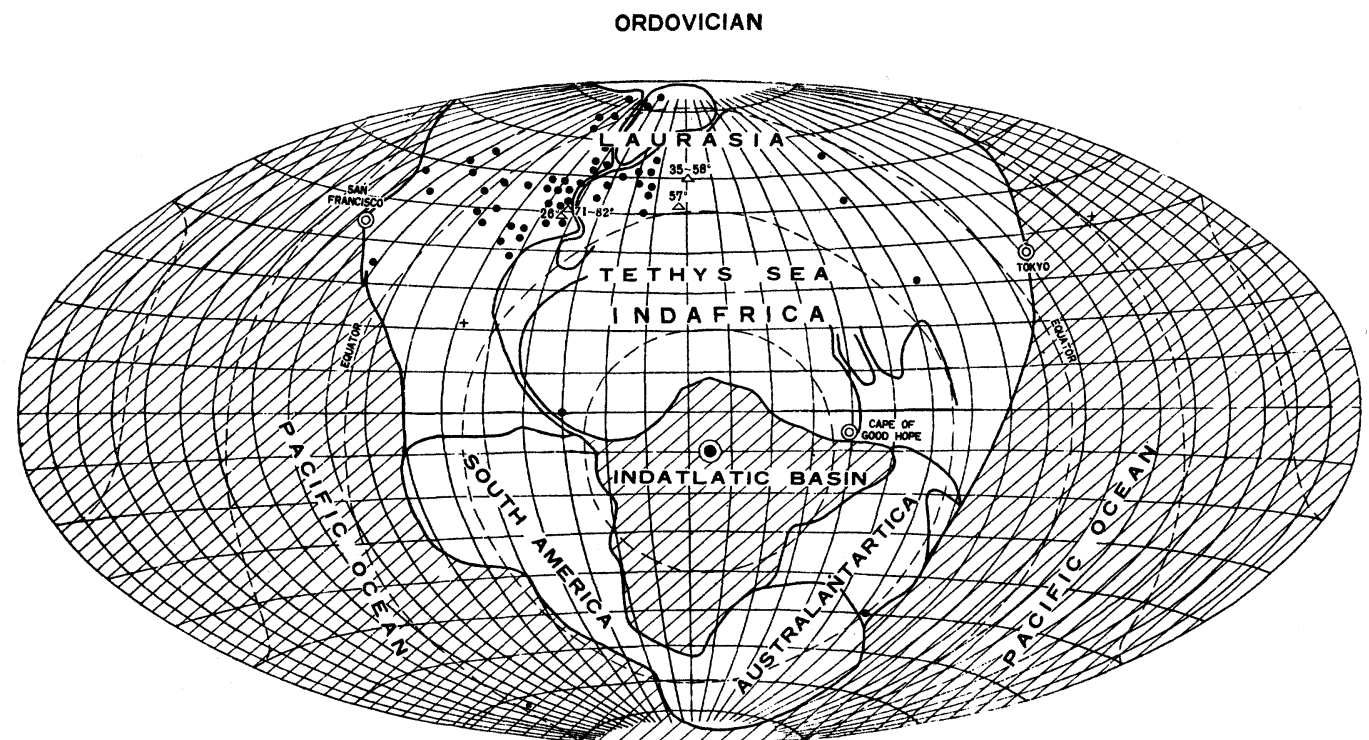

Localities of fossil corals.

$\triangle$ Magnetic latitudes.

+ Magnetic poles from Europe

Fig. 1b. The relative positions of continents during the Ordovician with reference to Eurasia in its present position 


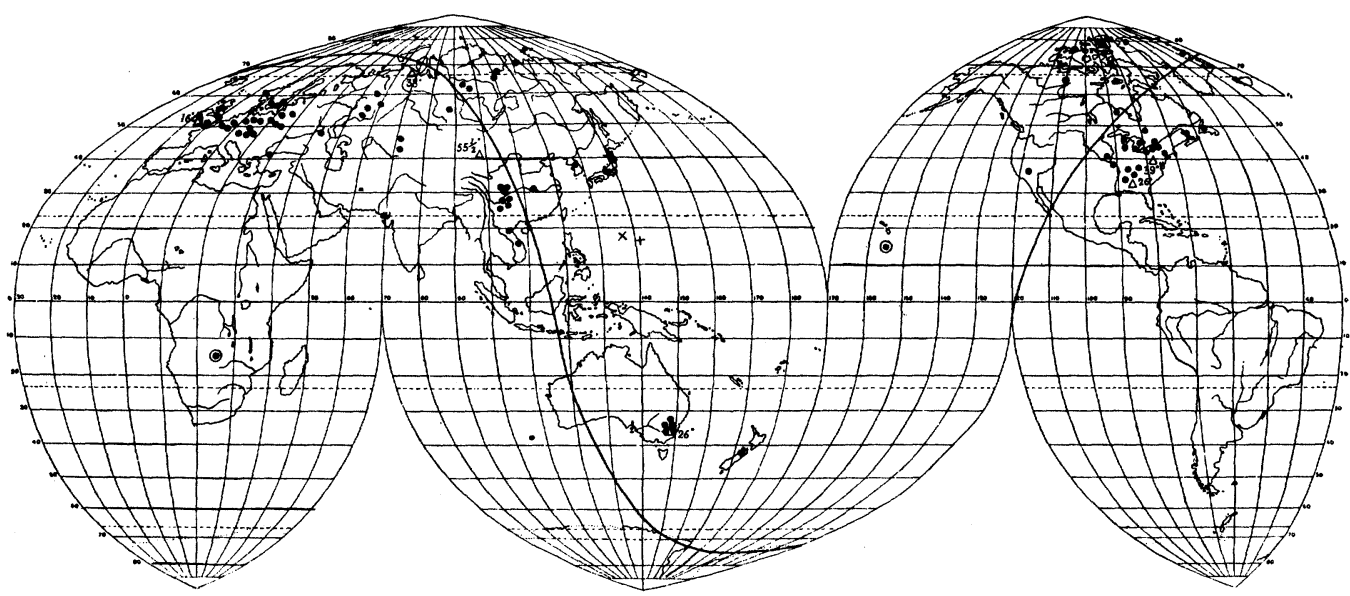

- The Silurian equator with respect to the present mesh of latitudes and longitudes on Eurasia and the corresponding poles.

The Silurian equator with respect to the present mesh of latitudes and longitudes on North America.

- Localities of fossil corals.

$\triangle$ Magnetic latitudes.

+ Magnetic poles from Europe. $\times$ Magnetic poles from North America

Fig. 2a The alignment of segments of the Silurian coralline sea on the present continents.

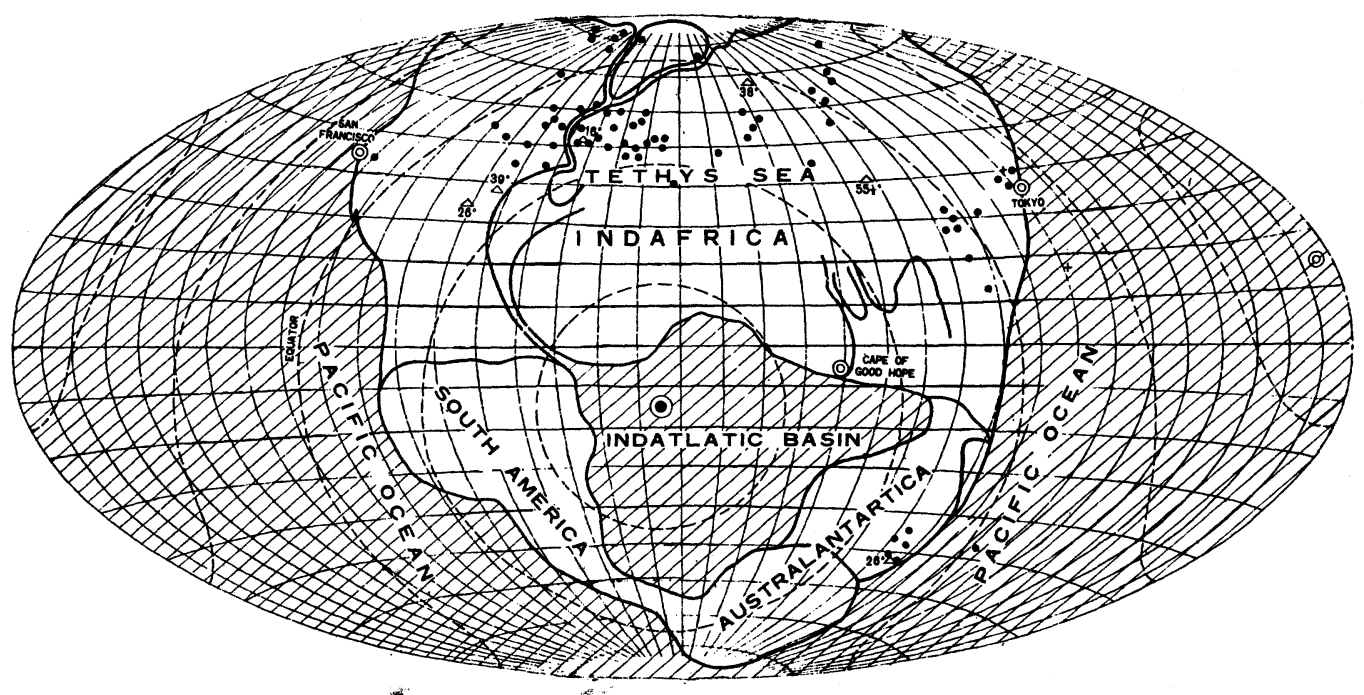

Localities of fossil corals.

$\triangle$ Magnetic latitudes.

+ Magnetic poles from Europe.

Fig. 2b. The relative positions of continents during the Silurian with reference to Eurasia in its present position 


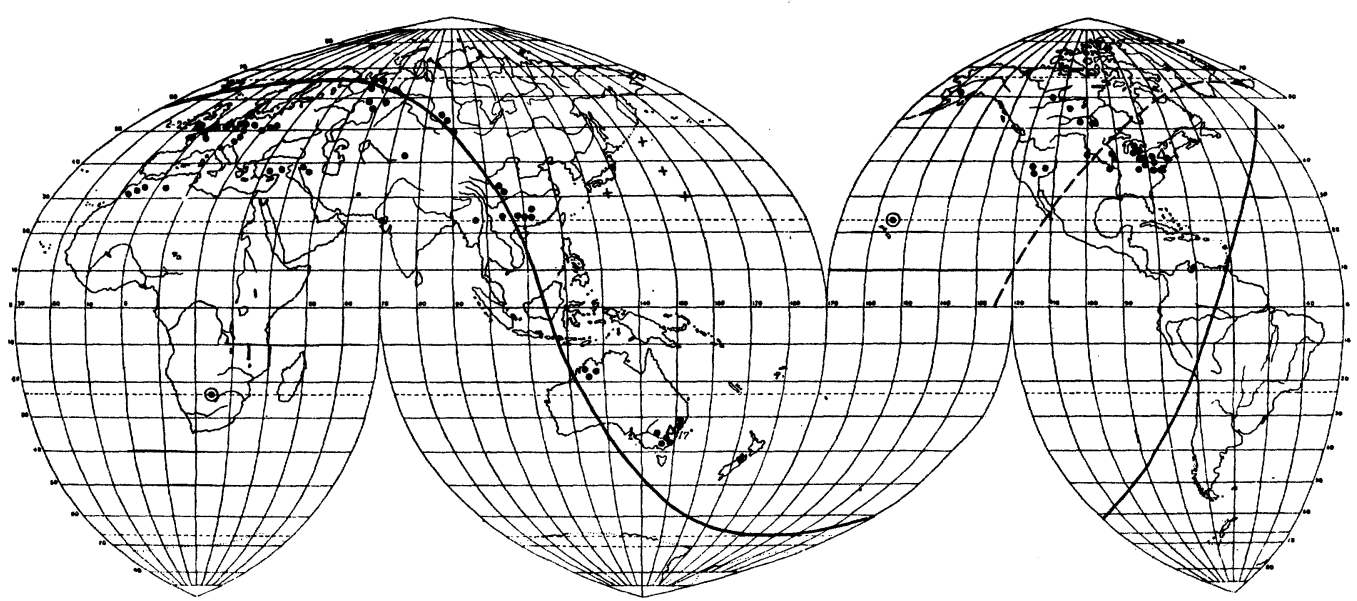

The Devonian equator with respect to the present mesh of latitudes and longitudes on Eurasia and the corresponding poles ...... The Devonian equator with respect to the present mesh of latitudes and longitudes on North America.

- Localities of fossil corals

$\triangle$ Magnetic latitudes

+ Magnetic poles from Europe.

$\times$ Magnetic poles from North America.

Fig. 3a. The alignment of segments of the Devonian coralline sea on the present continents.

DEVONIAN

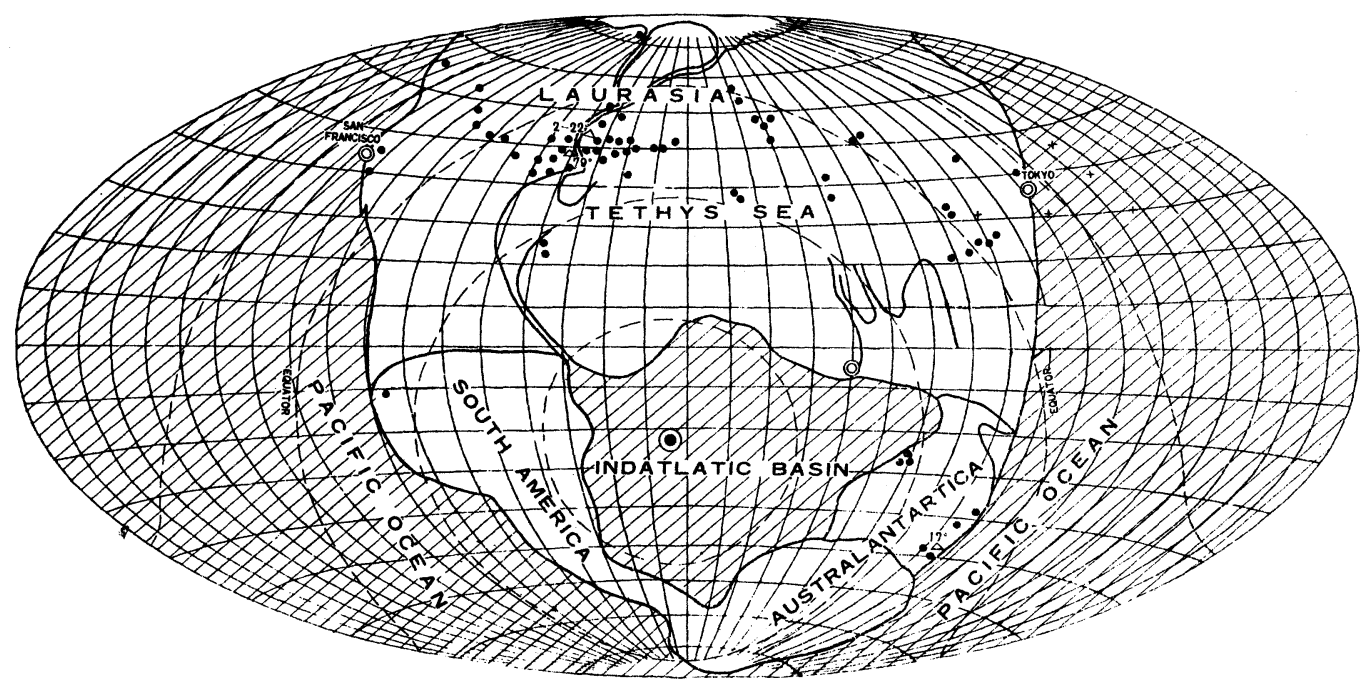

- Localities of fossil corals.

$\triangle$ Magnetic latitudes.

+ Magnetic poles from Europe.

Fig. $3 \mathrm{~b}$. The relative positions of continents during the Devonion with reference to Eurasia in its present position. 


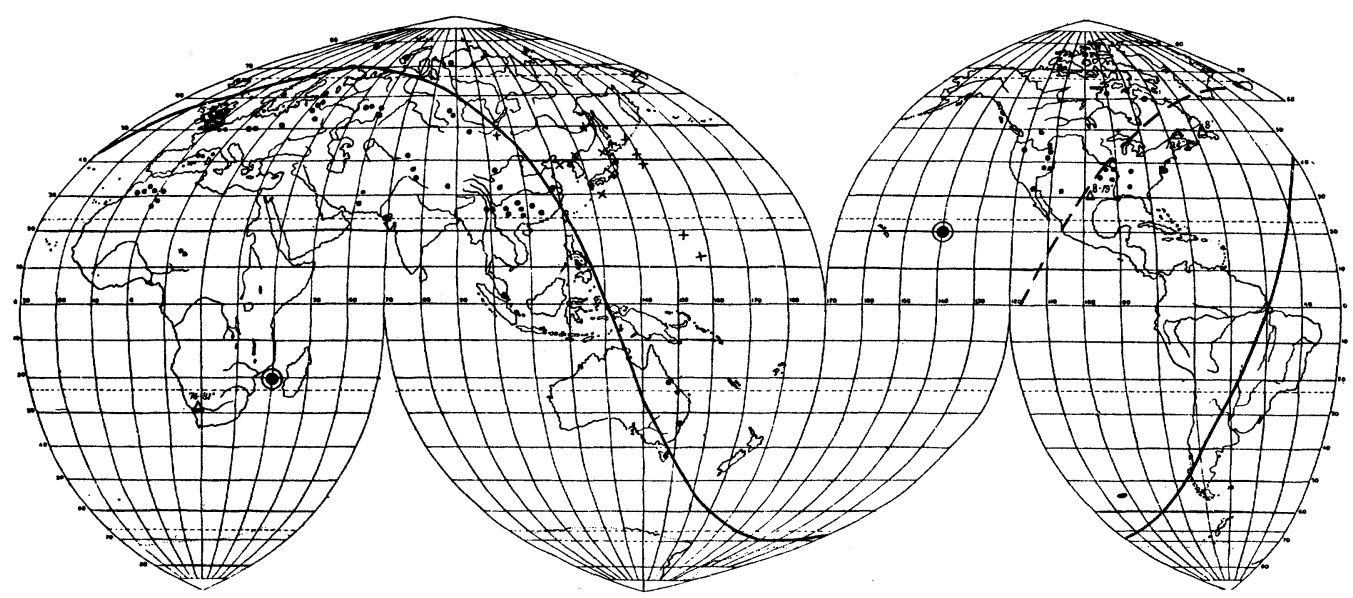

- The Lower Carboniferous equator with respect to the present mesh of latitudes and longitudes on Eurasia and the corresponding poles.

...... The Lower Carboniferous equator with respect to the present mesh of North America.

Localities of fossil corals.

$\triangle$ Magnetic latitudes.

+ Magnetic poles from Europe.

$\times$ Magnetic poles from North America.

Fig. 4a. The alignment of segments of the Lower Carboniferous coralline sea on the present continents.

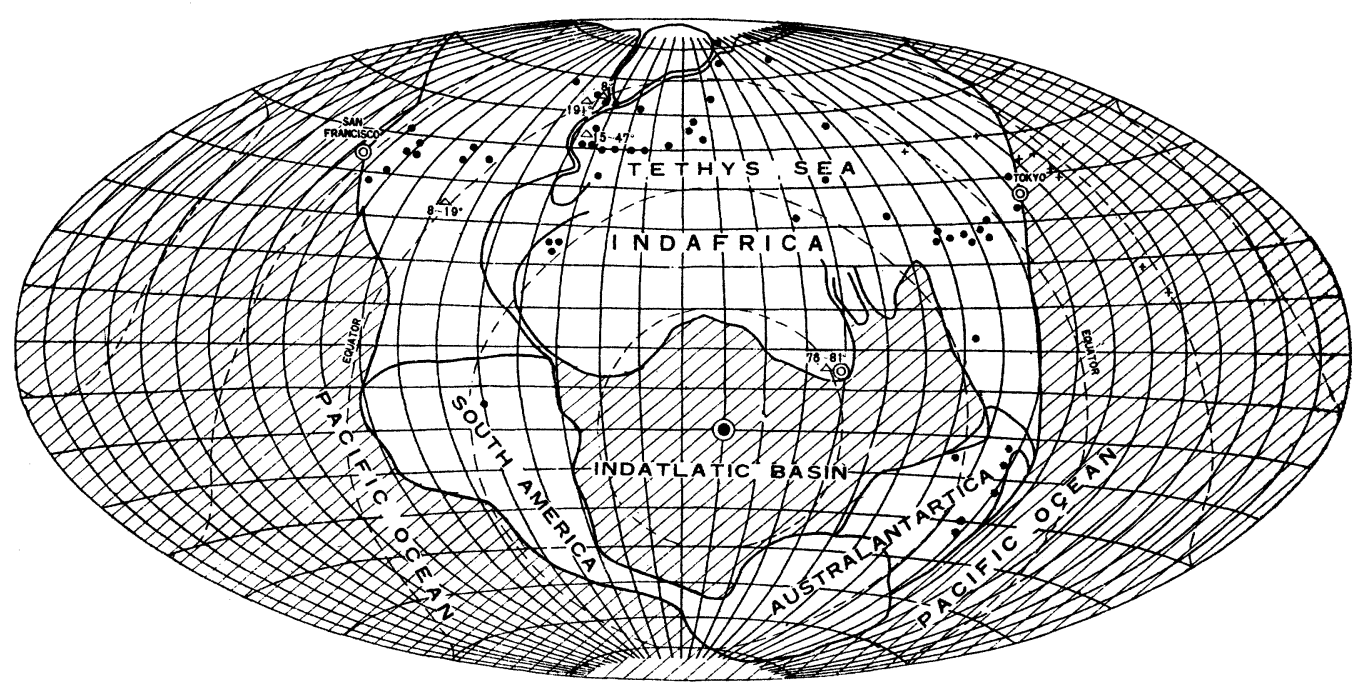

Localities of fossil corals.

$\triangle$ Magnetic latitudes

+ Magnetic poles from Europe.

Fig. 4b. The relative positions of continents during the Lower Carboniferous with reference to Eurasia in its present position. 


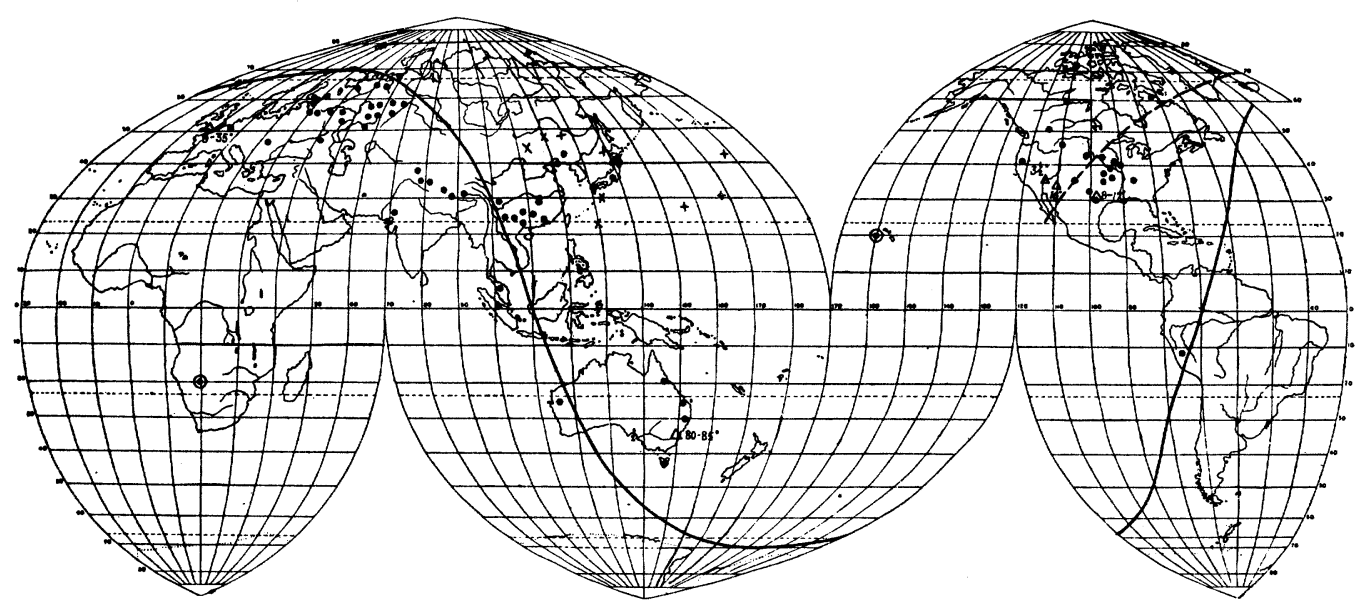

- The Upper Carboniferous equator with respect to the present mesh of latitudes and longitudes on Eurasia and the corresponding poles

....... The Upper Carboniferous equator with respect to the present mesh of latitudes and longitudes on North America

- Localities of fossil corals.

$\triangle$ Magnetic latitudes.

+ Magnetic poles from Europe.

$\times$ Magnetic poles from North America.

Fig. 5a. The alignment of segments of the Upper Carboniferous coralline sea on the present continents.

UPPER CARBONIFEROUS

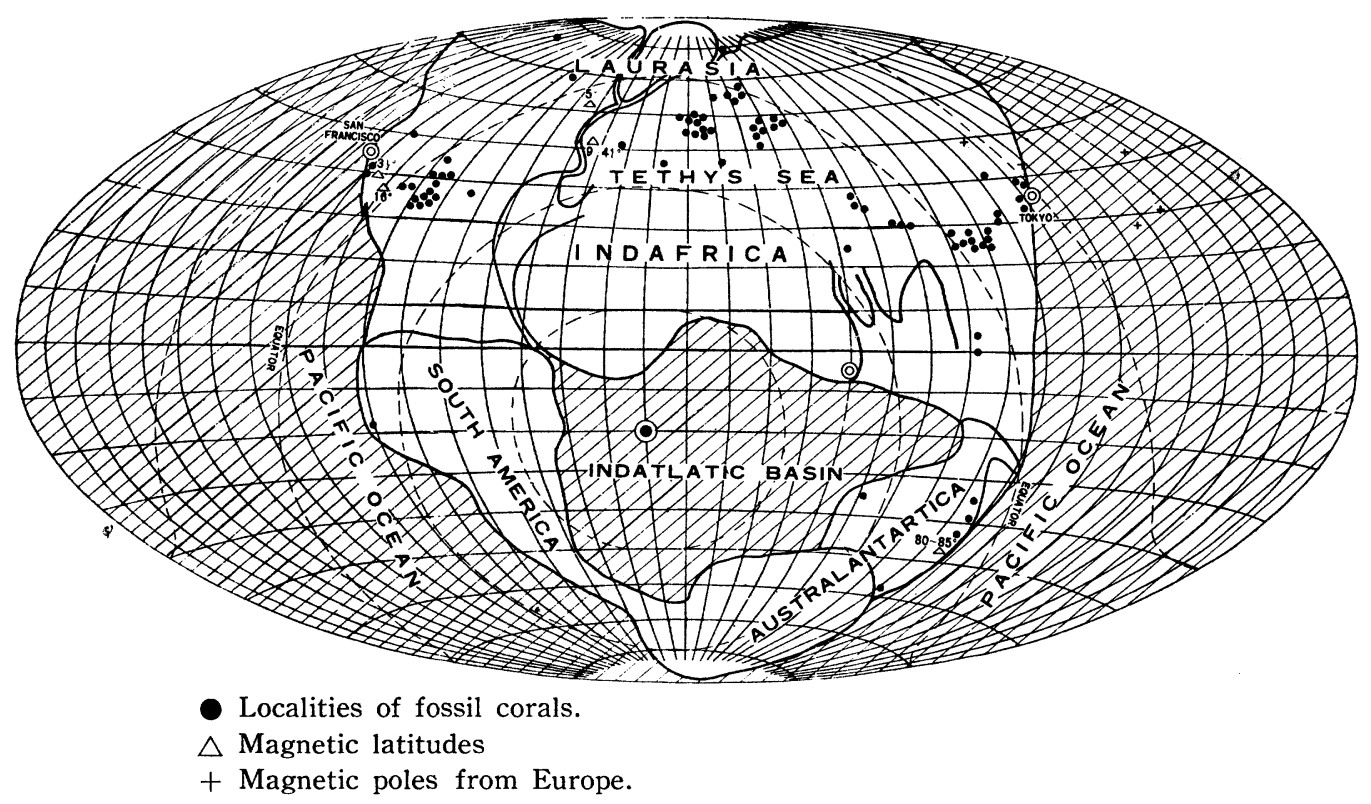

Fig. 5b. The relative positions of continents during the Upper Carboniferous with reference to Eurasia in its present position 


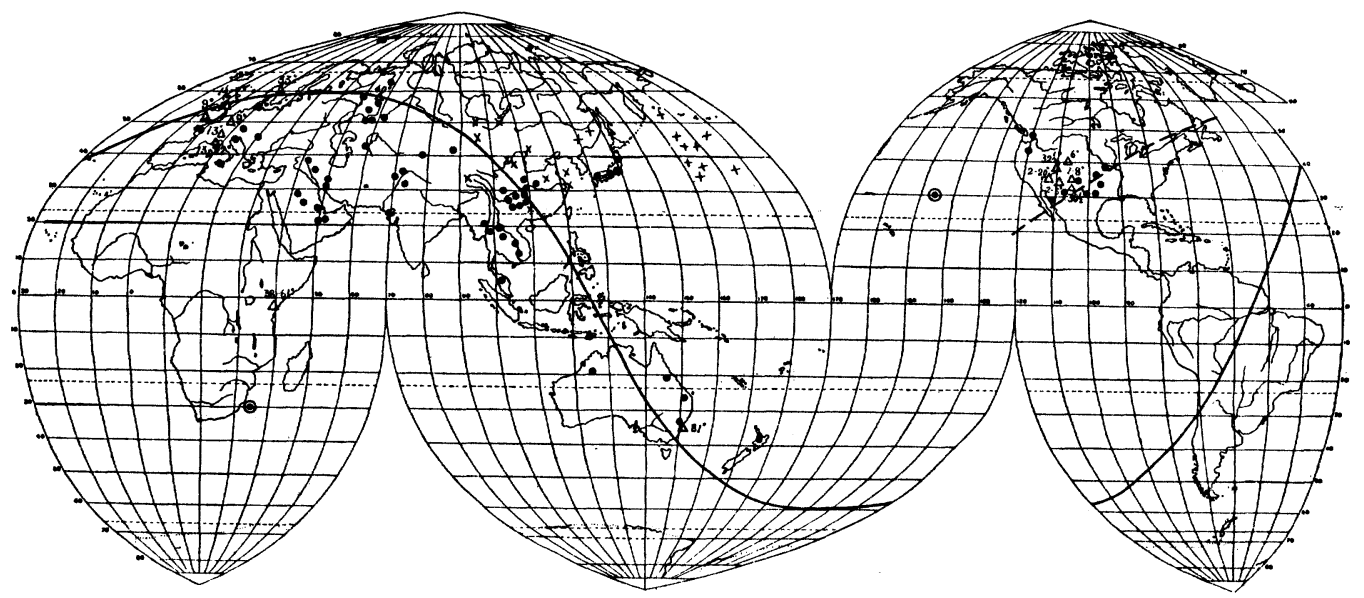

- The Permian equator with respect to the present mesh of latitudes and longitudes on Eurasia and the corresponding pcles

….. The Permian equator with respect to the present mesh of latitudes and longitudes on North America

- Localities of fossil corals.

$\triangle$ Magnetic latitudes.

+ Magnetic poles from Europe

$\times$ Magnetic poles from North America.

Fig. 6a. The alignment of segments of the Permian coralline sea on the present continents.

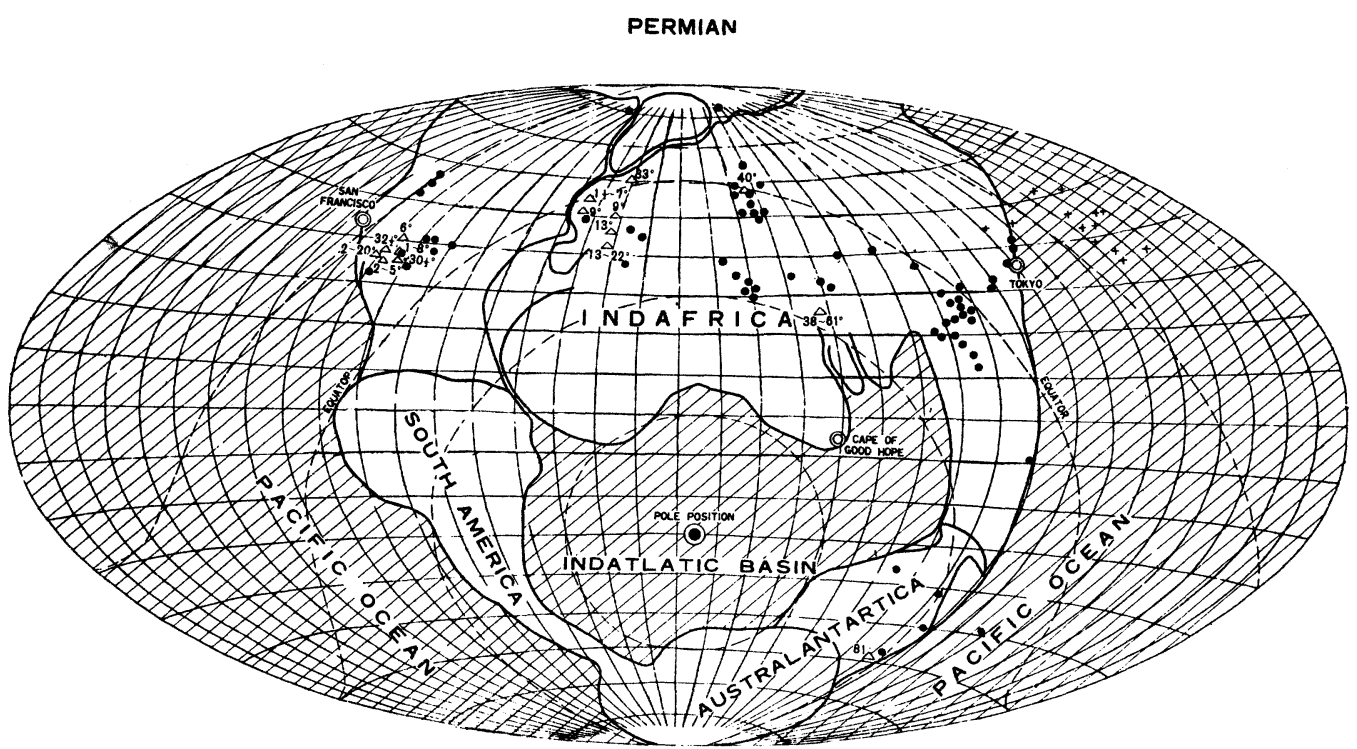

- Localities of fossil corals.

$\triangle$ Magnetic latitudes.

+ Magnetic poles from Europe

Fig. 6b. The relative positions of continents during the Permian with reference to Eurasia in its present position. 


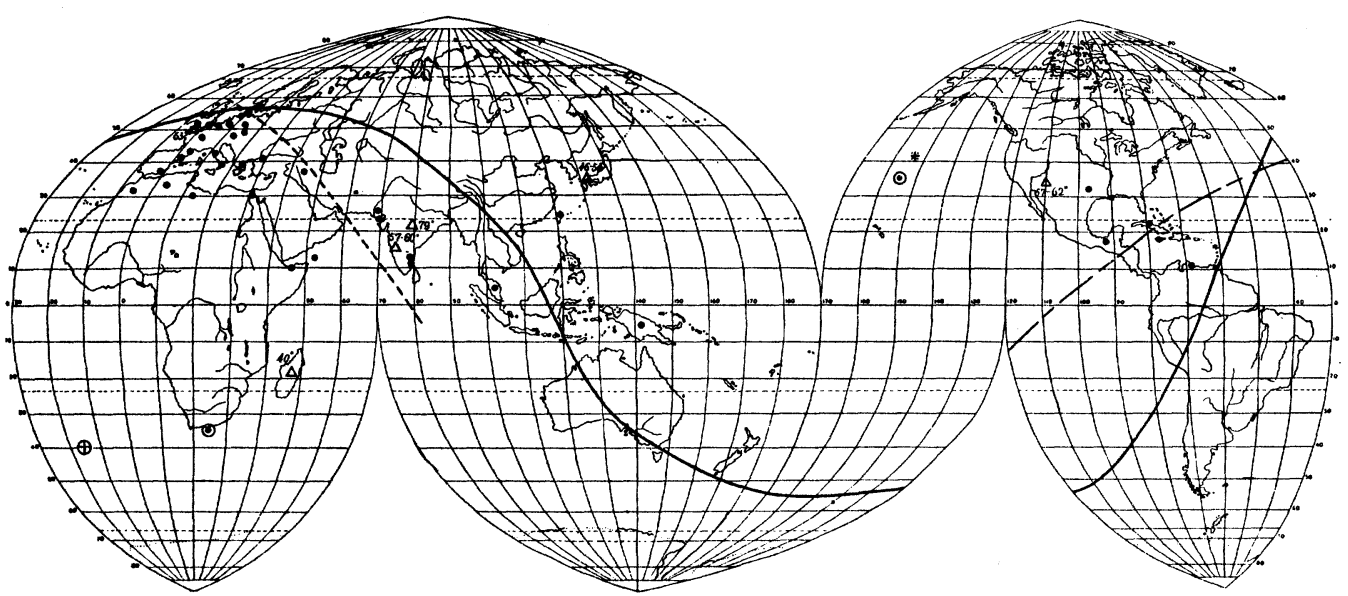

The Upper Cretaceous equator with respect to the present mesh of latitudes and longitudes on Eurasia and the corresponding poles.

-_. $\oplus$ The Upper Cretaceous equator with respect to the present mesh of latitudes and longitudes on North and Central America and one corresponding pole.

- - The Upper Cretaceous equator with respect to the present mesh of latitudes and longitudes on Africa.

- Localities of fossil corals.

$\triangle$ Magnetic latitudes.

+ Magnetic poles from Europe.

※ Magnetic poles from Japan.

$\times$ Magnetic poles from North America.

Fig. 7a. The alignment of segments of the Upper Cretaceous coralline sea on the present continents.

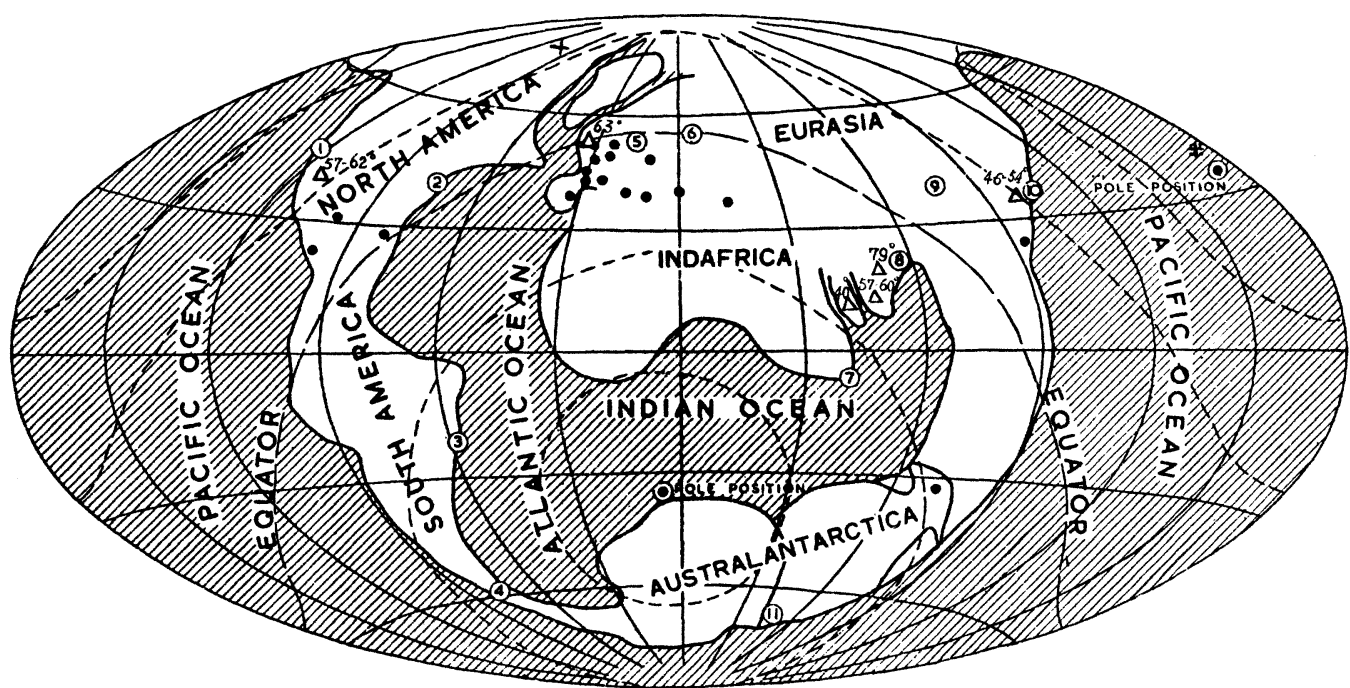

Localities of fossil corals.

$\triangle$ Magnetic latitudes

+ Magnetic poles from Europe.

$※$ Magnetic poles from Japan.

Fig. 7b. The relative positions of continents during the Upper Cretaceous with reference to

Eurasia in its present position. 1: San Francisco. 2: New York. 3: Rio de Janeiro.

4: Terra del Fuego. 5: Berlin. 6: Moscow. 7: Cape of Good Hope. 8: Calcutta.

9: Peiping. 10: Tokyo. 11: Tasmania. 
the tropics and subtropics of Eurasia and this brings out crustal movements including rotation of blocks or crustal masses and changes of intra-continental positions. The areas where magnetic measurements have been made in North America for the Ordovician and Silurian are all in the hemisphere on the side of the geographical pole position in Africa, but because these areas are all in low latitudinal positions pointing to the other pole are not easily detectable. The only determination of a magnetic latitude from North America for the Devonian disagrees greatly with the geographical latitude of the place determined from the central line of the coralline sea and the magnetic pole deduced is not discussed. The magnetic poles determined from low latitudes in North America for the Lower and Upper Carboniferous and Permian all fall in the North Pacific or Eastern Asia mostly around the geographical pole position determined from the coralline sea of North America but one locality where the magnetic inclination and declination were measured is on the other side of the equator.

The difference of the geographical pole positions determined from the fossil coralline seas of North America and Eurasia brings out the drift and rotation of North America with respect to Eurasia. The magnetic poles determined from North America can also bring out the relative drift and rotation of that continent. Taking as correct one magnetic pole determined from Europe without considering changes in intra-continental positions of Eurasia and the other magnetic pole determined from North America without considering its relative drift with respect to Eurasia, and confusing them as one in the fossil coralline seas of Eastern Asia would lead to postulated palaeomagnetic polar wandering curves for the different continents which would certainly disagree with the palaeogeographical latitudes or pole positions. Taking the high inclination of the Upper Carboniferous and Permian rocks in Australia as near the pole and agreeing with glaciation of the same age in Australia is also being misled because, as I have proved, the late Palaeozoic glaciation in Australia was all due to altitude (Ma, 1961a).

\section{Bibliography}

Chang, N.W. and Nairn, A.E.M. 1959. Some Palaeomagnetic Investigations on Chinese Rocks, Nature, vol. 183, pp. 254-255.

Cox, A. and Doell, R.R. 1960. Review of Palaeomagnetism, Geol. Soc. Am., Bull., vol. 71, pp. 645768,36 figs.

Creer, K.M., Irving, E., Nairn, A.E.M. and Runcorn, S.K. 1958. Palaeomagnetic Results from Different Continents and Their Relation to the Problem of Continental Drift, Annales de Géophysique vol. 14, No. 4, pp. 492-501, 7 figs.

David, T.W.E. 1950. The Geology of the Commonwealth of Australia, edited and much supplemented by W.R. Brown, vol. 1 .

Deutsch, E.R. 1958. Recent Palaeomagnetic Evidence for Northward Movement of India, Alberta Soc. Petr. Geol., Jour., vol. 6, No. 6, pp. 155-162, 1 fig.

Duncan, P.M. 1861. A Description, and Remarks upon, Some Fossil Corals from Sinde, Ann. Mag. Nat. Hist., III, 13, pp. 296-306, pls. 18 \& 19.

Duncan, P.M. 1869-70. Monograph of British Fossil Corals, being a suppl. to the monograph of 
British fossil corals, by M. Edwards and J. Haime, Pal. Soc. London.

Duncan, P.M. 1880. Sind Fossil Corals and Alcynaria, Geol. Surv. India, Mem., Pal. India, Tertiary and Upper Cretaceous Fauna of West India, XIV, (1), 1.

George, J.W. 1930. The fossil Fauua of the Samana Range and Some Neighbouring Areas, pt. 7 :

The Lower Eocene Corals, Pal. India, XV, 7, pp. 81-128, 2 pls.

Leed, H. 1956. Permian Reef-building Corals from North Auckland Peninsula, New Zealand, New Zealand Geol. Surv., Pal. Bull., 25, pp. 15-24, pls. 3-5.

Ma, T.Y.H. 1933. On the Seasonal Change of Growth in Some Palaeozoic Corals, Imp. Acad., Tokyo, Proc., vol. 9, pp. 407-409.

Ma, T.Y.H. 1934. On the Growth Rate of Reef Corals and the Sea Water Temperature in the Japanese Islands during the Last Geological Times, Tôhoku Imp. Univ., Sendai, Japan, Sci. Rept., 2nd Ser. (Geol), vol. 16, No. 3, pp. 166-189, pls. 1-9.

Ma, T.Y.H. 1937. On the Seasonal Growth in Palaeozoic Tetracorals and the Climate during the Devonian Period, Pal. Sinica, Ser. B, vol. 2, fasc. 3, 96 pp., 22 pls.

Ma, T.Y.H. 1937a. On the Growth Rate of Calapoecia canadensis Billings, and the Climate of the Arctic Regions during the Ordovician Period, Geol. Soc. China, Bull., vol. 17, No. 2, pp. 177182.

Ma, T.Y.H. 1937b. On the Ordovician Climate of the Northern Hemisphere Deduced from the Growtr Rate of Tabulate Corals, Geol. Soc. Japan, Jour., vol. 44, pp. 931-938; Pal. Soc. Japan, Trans Proc., No. 48, pp. 138-143.

Ma, T.Y.H. 1943. The Climate and the Relative Positions of Eurasia and North America during the Ordovician Period as Determined by the Growth Rate of Corals, Research on the Past Climatt and Continental Drift, vol. 1, 33 pp., 2 maps.

Ma, T.Y.H. 1943a. The Climate and Relative Position of Continents during the Silurian Period as Determined by Growth Rate of Corals, Research on the Past Climate and Continental Drift, vol 2, 115 pp., 14 pls., 3 maps.

Ma, T.Y.H. 1943b. The Climate and the Relative Position of Continents during the Devonian Period Research on the Past Climate and Continental Drift, vol. 3, 92 pp., 3 maps.

Ma, T.Y.H. 1951. The Equator and the Relative Positions of the Continents during the Cretaceou: Period as Deduced from the Distribution and Growth Values of Reef Corals, Research on thi Past Climate and Continental Drift, vol. 4, 25 pp., 1 fig., 1 pl.

Ma, T.Y.H. 1952. Shiftings in Pole-Positions with Diastrophisms since the End of the Cretaceou: and the Accompanying Drift of Continents, Research on the Past Climate and Continental Drift vol. 5, 172 pp., 22 pls., 1 chart.

Ma, T.Y.H. 1953. The Sudden Total Displacement of the Outer Solid Earth Shell by Slidings Relativı to the Fixed Rotating Core of the Earth, Research on the Past Climate and Continental Drift vol. 6, $15 \mathrm{pp}$.

Ma, T.Y.H. 1955. Climate and the Relative Positions of the Continents during the Lower Carboni ferous, Research on the Past Climate and Continental Drift, vol. 7, 99 pp., 50 pls.

Ma, T.Y.H. 1955a. Alteration of Sedimentary Facies on the Ocean Bottom and Shortness of th. Period of Diastrophism after a Sudden Total Displacement of the Solid Earth Shell, Oceanographi, Sinica, vol. 2, fasc. 1, 17 pp.

Ma, T.Y.H. 1955b. The Geological Significance of the Continental Shelf and the Accumulation o Continental Slope Deposits, Oceanographia Sinica, vol. 2, fasc. 2, 9 pp.

Ma, T.Y.H. 1956. A Reinvestigation of Climate and the Relative Positions of Continents during 
the Devonian, Research on the Past Climate and Continental Drift, vol. 9, 116 pp., 70 pls.

Ma, T.Y.H. 1956a. A Reinvestigation of Climate and the Relative Positions of Continents during the Silurian, Research on the Past Climate and Continental Drift, vol. 10, 92 pp., 56 pls.

Ma, T.Y.H. 1956b. Climate and the Relative Positions of Continents during the Ordovician, Research on the Past Climate and Cotinental Drift, vol. 11, 25 pp., 10 pls.

Ma, T.Y.H. 1956c. Geological Verification of the Theory of Sudden Slidings of the Solid Earth Shell over the Liquid Core, 8th Pacific Science Congress, Philippines, Proc. vol. 11 A, pp. 731-743.

Ma, T.Y.H. 1957. Continental Drift and the Present Velocity of Shift of the Continental Margin of Eastern Asia, Research on the Past Climate and Continental Drift, vol. 12, 22 pp.

Ma, T.Y.H. 1957a. Climate and the Relative Positions of Continents during the Upper Cretaceous, Research on the Past Climate and Continental Drift, vol. 13, 69 pp.

Ma, T.Y.H. 1957b. Geological and Geophysical Development of the Structures along the Continental Slopes of the Circum-Pacific Coast and the True Concept of A Geosyncline, Oceanographia Sinica, vol. 4. fasc. 1, 9 pp.

Ma, T.Y.H. 1958. The Relation of Growth Rate of Reef Corals to Surface Temperature of Sea Water as Basis for Study of Causes of Diastrophisms Investigating Evolution, Research on the Past Climate and Continental Drift, vol. 14, 60, pp., 24 pls.

Ma, T.Y.H. 1959. Effect of Water Temperature on Growth Rate of Reef Corals, Oceanographia Sinica, Special Volume, No. 1, 116 pp., 321 pls.

Ma, T.Y.H. 1960. Continental Drift and Polar Wandering, Research on the Past Climate and Continental Drift, vol. 15, 24 pp., 7 pls.

Ma, T.Y.H. 1960a. Climate and the Relative Positions of Continents during the Upper Carboniferous as Deduced from the Growth Values of Reef Corals, Research on the Climate and Continental Drift, vol. 16, $21 \mathrm{pp.}$

Ma, T.Y.H. 1960b. A Comparison of Palaeomagnetic Latitudes and Palaeogeographical Latitudes Deduced from Growth Values of Reef Corals, Oceanographia Sinica, vol. 6, fasc. 2, 5 pp.

Ma, T.Y.H. 1960c. My Genetic View of Major Structures on the Ocean Floor, Oceanographia Sinica, vol. 6, fasc. 1, 18 pp.

Ma, T.Y.H. 1961. Climate and the Relative Positions of Continents during the Permian as Deduced from the Growth Rate of Reef Corals, Geol. Soc. China, Proc., No. 4, pp. 91-102.

Ma, T.Y.H. 1961a. Causes and Process of Development of Palaeozoic Glaciation, MS.

Ma, T.Y.H. and Pan, C.L. 1955. An Orogenic Interpretation of Island Arcs, Research on the Past Climate and Continental Drift, vol. 8, 12 pp.

Nairn, A.E.M. 1960. Palaeomagnetic Results from Europe, Jour. Geology, vol. 68, pp. 285-306.

Nairn, A.E.M. 1960a. A Palaeomagnetic Survey of the Karroo System, Overseas Geol. \& Mineral Res., vol. 7, No. 4, pp. 396-410.

Runcorn, S.K. 1958. Palaeomagnetism, Address to Simposium on Polar Wandering and Continental Drift, Alberta, Soc. Petro. Geol. Jour., vol. 6, pp. 139-144.

Schove, D.J., Nairn, A.E.M. and Opdyke, N.D. 1958. The Climate Geography of the Permian, Sartyck ur Geografiska Annaler, vol. 40, No. 2-4, pp. 216-231, 7 figs.

\section{DISCUSSION}

S. Uyeda :

Speaking of India, for instance, is not there any way of avoiding the disagreement by moving India in the Cretaceous to somewhere else? 
T.Y.H. Ma :

From both the distribution of growth values of fossil reef corals and coralline sea which surrounded India, there is no way to move India from low to high latitudinal position.

K. Kobayashi :

I would like to ask any of participants about their opinion on a hypothesis implying that the earth has become warmer or cooler as a whole rather cyclicly in the long geological period.

I have no particular comment on this problem, but it is necessary to exclude such a possibility for the purpose of comparing the palaeomagnetic results with palaeoclimatological ones, I think.

T.Y.H. Ma :

There has been no change in temperature on sea surface in the respective latitudes in the Palaeozoic periods as shown by the distribution of growth rates of fossil corals. 